\title{
A diachronic view upon the Bals media
}

\author{
Mihaela-Gabriela Păun \\ Secondary School No. 1, 26 Cireșului Street, Balș, Olt County, Romania \\ E-mail: mihapau75@yahoo.com
}

\begin{abstract}
The study constitutes an application on the journalism field. Analyzing media outlets media operators that existed in the Bals city resulted: a) the existence of an intense journalistic activity in the city Bals starting with the year 1900; b) journalistic activity survived in time and continues to exist up to present. Research concludes that the written media from the city Bals begins to be noticed around the year 1900, it culminates in the inter-war period, through the academician Petre Pandrea who was born here and it had an intense journalistic activity; it is almost inexistent in the communist period and in present, still resist the time through the scholar publications and the people involved in the written media. An important figure of actual written media is Andrei Lupu.
\end{abstract}

Keywords: journalism; the media from Bals; local newspapers; journalistic activity

\section{INTRODUCTION}

Situated in the S-V of the Olt district, the city Bals from nowadays, was appreciated in 1916 by a traveler in the pages of the magazine "Licariri" as being : "a small village, although it gives the impression of a city. Broken in two, in the middle by the small river Oltet, was associated by the inhabitants, with Budapest and not rarely you can hear talking about Buda or Pesta, meaning the parts of Bals from this side and from the other side of the great iron bridge built in the year 1986 and which gives a magnificent aspect to this village. Alongside the Oltet, which sometimes flows so nicely, that its waves seem furious and threatening billows, there is a small but nice park, which during the summer is quite often frequented and where sometimes popular holidays are celebrated by the schools of the city. In spring, when the trees start to blossom ,the park seen from the bridge, delights the eyes with the most beautiful views, the nightingales are in competition, the birds hum tender, and the echo carries above the water a concert which attracts you in the middle of the trees, on the hidden paths and solitary traces where you can quietly dream and where in the morning and twilight the silence penetrates the bottom of the soul (...) once you get out of the village, you know that in summer a blinding dust is waiting for you, and in spring and autumn a terrible mud" (Licariri,1916, p. 1). Born in Bals, Petre Pandrea finds a constant refugee in the "area of the peasants 'origins", feeling close to them because: "People change, but the park remains the same. The impression of eternity is overwhelming. "(Moisa, 2008 p. 17, p. 186; see also Anghelescu, 2013).

In this topos, the media remarks starting with the year 1900, when in 16 April, appears the weekly newspaper "Zefirul", as we know from some sources. In the library of the Academy, the newspaper "Zefirul" appears to be printed at the publishing company of N. I. Macavei 
starting with the year 1890 and it has a monthly apparition. Its director is Al. M. Constantinescu and is included in the "Romanian Periodical Publications", vol. 1, pag. 806 (Regneală, 2001; Regneală, 2009). In 1904 appears the monthly magazine "Vorbe Bune", anul I, 1 September, the director being G. Vasilescu-Bals.

The magazine appears from the desire to "cultivate the mind and heart, to guide us through ourselves [...] to a life according to the time and circumstances we live in "(Vorbe Bune, p. 1). G. Vasilescu will also coordinate starting with the year 1929, as director, the activity of the magazine "Tarancuta", which used to appear twice a month, patronized by the Cultural Committee "Sfanta Cruce" and having the redaction and administration in Bals. It presents news from Bals, an advice accessible to everyone, and literary works. Between the years 1905-1906 it appeared the newspaper "Gazeta Balsului: Ziar Independent" whose owner was N. Pompilian, with a publishing break in the period 12 December 1905-13 February 1906. Other two numbers will be published in 1925. Also, this weekly newspapers mentioned in the Romanian Periodical Publications: vol. 1, pag. 281-282, but there is mentioned also in "Dictionarul istoric al localitatilor din judetul Olt", where we find out that the publications from Bals were:" Gazeta Balsului (23 oct. 1905-13 feb. 1906, 15 oct. 1925), Licariri (1 august 1915iulie 1916), "Tarancuta", cultural and politic, being published under the name: "Biblioteca Lumina pentru toti" in 1931 ("Dictionarul istoric al localitatilor din judetul Olt, p. 185).

\section{JOURNALISTIC DETAILS}

The most known magazine, from which today a number is kept at the library of the city "Petre Pandrea" from Bals, is called "Licariri". It is published starting with 1 August 1915, the founding members being: Stefan Mihaescu, Teodor Tofilescu, Theodor N. Preda, Ioan M. Ionila, Barza, Incognitus, student from high school, Nicolae M. Dumitru, highschool student, Dumitru I. Marcu, high school student, and as members of honour: judge Paul Ionescu Pastion and teacher Constantin Dinculescu (Licariri, 1915, p. 1). The magazine addresses specially to the students and youngsters in general. In the monography of the city Bals we find "the reproduction from the "Minerva" newspaper about the magazine "Licariri": the magazine "Licariri" was published. The editorial office and administration is in Bals-Romanati It is a rare beam which sparkles in the darkness of the villages where there are so many needs...Very interesting for the youngsters and the population from the countryside" (City Bals Monography, 2013, p. 143). Mircea Moisa in "Caleidoscop la purtator" identifies after a study of the publication, that the "winner of the monthly magazine "Licăriri" from Bals was Gh. I. Mihaiescu", the writer (M. Moisa, 2011, p. 191; Paun, 2013; Păun, 2014).

The famous son of the city, the post-mortem academician Petre Pandrea "wrote several articles in the inter-war period in magazines such as: "Gandirea", "Viitorul Social", "Stanga" and "Cuvantul Liber". He creates great debate when he writes "Manifestul Crinului Alb" in "Gandirea", together with Sorin Pavel and Ion Nistor (Infocarte, 2009). Adrian Bucurescu, in an article from Romania Libera, specifies that Petre Pandrea begins at 19 years, in the magazine "Gandirea", with the article "Literatura care ne lipseste". Since that time he became very active in the cultural life, collaborating intensely at many magazines [...]. He published himself the magazines "Viitorul Social", "Stanga si Cuvantul Liber" (Adrian Bucurescu, 2008; Vlăduțescu, 2013a).

Nowadays, every school from Bals has at least a magazine. From these, we mention a few: Middle School Nr.1 with "Prietenia", coordinated by the teacher Costache Mihaela, published from 2009 up to now, Middle School "Mihail Drumes" has an intense activity 
through the magazine "Din umbra talentului", coordinated by the teachers: Guran Daniel, Nicola Daniela and Mainescu Corina, the magazine for culture and free time "Mihail Drumes dincolo de timp", coordinated by the teachers: Guran Daniel, Tabarta Elena and Costache Mirela, who coordinated also the magazine: "Muguri de speranta" in 2010-2011 (Vlăduțescu, 2014; Bitoleanu, 2014). It must be mentioned that at this school, between the years 2005-2010 it was also published the magazine "Campionii", coordinated by teacher Guran Daniel. At the ex-Agricol Highschool (today Technique College) in 2010 it was published the magazine "Vlastarul", coordinated by teacher Strambeanu Daniel; the magazine "Altfel", of the Petre Pandrea Highschool, coordinated by teacher Nicolae Loghinas and the magazine "Natura încotro?" coordinated by teacher Tanasie Mariana; the magazine "Licurici", of the Kindergarten "Ion Creanga", with the following editorial office: the cover: Costea Andreea, correction: Costea Manti, computerized graphics: Guran Simona and editors: Sarbu Nicolita, Costea Manti, Guran Simona, which is published starting with the year 2010.

The city Bals, the third one, considering the number of inhabitants from Olt district and" an old village" which connects the two residencies Craiova and Slatina, had along the time a journalistic activity, worth to be remembered nowadays. The city which gave to Oltenia important names such as Petre Pandrea, known for his journalistic activity, as we have mentioned before, it also has today an important journalistic activity (Strechie, 2010; Vlăduțescu, 2013c).

In order to go deep into the mistery of this handcraft and unpuzzle it, we initiated a debate with the journalist Andrei Lupu, who was born in this city and now writes about it.

"Mister Andrei Lupu, thank you for your availability to answer a few questions. In present, you are a journalist at "Gazeta Noua" from Slatina and the only one from Bals. What determined you to chose the job of journalist?

A: I want to start by saying that it is somehow an awkward situation, because usually I am the one who asks questions in interviews, and the speakers give me the answers. Indeed, from about six years I am the editor of the newspaper Gazeta Noua (ex-Monitorul de Olt) and I am writing articles about Bals. The job of journalist, came into mind in the ninth grade, when I regularly participated at the meetings of the painters and poets from the district, in the art salon Pro Art-Despi Club from the city. The reason for which I attended this meetings or the literary cafes, was that during that time I was writing poetry and I liked to make myself known into this field, the experienced poets and the older ones allowed me to step forward with the lyrics written by me.

During this time, I also got into contact with many people from media and around year 2003, at the age of 16, I was to publish my first poem in a newspaper from our district. And this was the spark which enflamed my interest for written media. Traveling with painters and poets from the city at different events continued and after that some collaborations for written articles or opinion surveys. After many unsuccessful attempts, to be hired at a newspaper from our district, the main cause being the fact that I was living in Bals, "the city were nothing happened", I managed to convince a director at a newspaper that I can assure the correspondence for this area. Since then, I believe, I demonstrated that this phrase" nothing happens here' is false and actually Bals has a lot of events worth to appear in a newspaper (Moraru, 1997; Vlăduțescu \& Ciupercă, 2013). I chose to frequent the Faculty of Journalism "Lucian Blaga" from Sibiu because at that time in Craiova didn't exist such specialization, in 2007. Bucharest seemed a city too busy and crowded for me. Everything that I knew about Sibiu gave me confidence. You should know, though that I am not the only journalist of this city, but the only one who writes about this city. So, I can remind Marin Trașcă, copy editor and man of radio in Madrid, who writes for the community of the Romanians from Spain, Elena 
Alexandra, copy editor at Digi Tv, Oana Danciu, Tv presenter, Mihaela Ene, copy editor at Romania Libera, Florentina Voicu, copy editor at Gazeta Oltului and others.

$\mathrm{R}$ : What can you tell me about your beginning and about inspiration?

A: Well I first needed to work for some newspapers that "forgot to pay the work", although the articles were published, until I managed to enter into a serious editorial office. As a proof, now I am on of the oldest employees of this newspaper. the inspiration exist, nevertheless, in us. Just that in media it is not enough to be inspired, you must follow some rules, because the texts you write must be professional. This question would be more appropriate for the time when I was writing poetry, because these were created totally from inspiration.

R: How hard is to do your job, nowadays?

A: It is not hard to do your job, as long as you don't' make compromises. The road can be followed in straight line as long as you are vertical, trust in yourself and impose your point of view. And after six years of written media with almost daily articles, nothing can be that hard.

$\mathrm{R}$ : The written media still survives in front of the internet?

A: Of course, now they survive at the same time, because every newspaper has an online edition, and the number of the ones who access every article is much bigger the invasion of the internet. But if you ask me if a newspaper survives from its selling, this thing is already a mith. from?

R: Bals News Administration. Can you tell me more about this? Where this idea came

A: Around the year 2008, a colleague from the newspaper suggested me to create a web page to publish my articles in the virtual field, because at that time, the newspaper where I was working didn't have a web page. I named my page Wolf press, and in time it was replaced by the site BalsNews.com. A friend of mine who was better than me in the informatics field, suggested me to create this site, for free, and after many discussions I accepted. In the last years, Bals News has suffered design changes and became the most accessed site from Bals. More than that, a link to the site was posted on the official site of the Mayors' s office from Bals, and the chapter" written media", was reminded in the only monography of the city Bals, published in the year 2013 .

$\mathrm{R}$ : What can you tell us about this journalistic species called interview?

A: The interview is the best method to intimidate the interlocutor, because many people think many times before answering the questions, for fear there might exist some subtitles hidden among the questions. Also, for an interview to be valuable, it is extremely important that the questions of the one who interviews be the proper ones, convincing and objective.

$\mathrm{R}$ : Thank you for your time and I wish you success in your career and in your personal life as well.

The city Bals, although it is the third city of the Olt district, and seems the place" where nothing happens", if we cite Mihail Sadoveanu, had and it has now a rich journalistic activity starting with the year 1900 and culminating with the interwar period when Petre Pandrea is remarked as a journalist born in Bals without having local activity. In the communist period, the journalistic activity of the city is weakly represented, practically the most known publications in the city, were the newspaper "Scanteia", and the magazine for children: "Cutezatorii", which were only distributed in the city . At present, there are scholar magazines and sons of Bals, involved in the written media and radio-TV. 


\section{CONCLUSION}

The written media of Bals affirms around the year 1900 when the first publications appear, through the gentleness of some people willing to "cultivate the mind and heart one another, to guide through ourselves [...] to a life in accordance to the times and surroundings we live in", as it is said in Vorbe Bune, p. 1. It culminated in the inter-war period through the academician Petre Pandrea who was born here and had an intense journalistic activity, even if he didn't live in the city, because he considered himself "an oltean and European as well"; it is almost inexistent in the communist period, and at present, it endures in time through the scholar publications and the people involved in mass-media, who were born, raised and even live in Bals, as the journalist Andrei Lupu.

\section{References}

[1] Borowski A. (a), International Letters of Social and Humanistic Sciences 6 (2013) 86-90.

[2] Păun Mihaela Gabriela, International Letters of Social and Humanistic Sciences 6 (2014) $42-48$.

[3] Borowski A. (b), International Letters of Social and Humanistic Sciences 7 (2013) 113-118.

[4] *** Balş-Mărturii. (2011). Primăria Balş, Biblioteca orăşenească Petre Pandrea Balş. Editura Premier LTD.

[5] Bănică Paula (2013). Monografia oraşului Balş. Balş: Editura: Premier LTD.

[6] Bucurescu Adrian, Petre Pandrea, un haiduc al cuvântului, România Liberă, 25 iulie 2008. Disponibil:http://www.romanialibera.ro/cultura/aldine/petre-pandrea-un-haiduc-alcuvantului-130405.html

[7] Pretorian Cristina, Ionescu Dan, International Letters of Social and Humanistic Sciences 9 (2014) 49-56.

[8] Vlăduţescu Ştefan (2004). Argumentaţia şi demonstraţia, ca moduri de impunere. Craiova: Editura Sitech.

[9] *** Infocarte. (2009). Disponibil:

http://www.infocarte.ro/petre-pandrea-despre-autor-1775

[10] Regneală Mircea (2001). Studii de biblioteconomie. Ed. Ex Ponto.

[11] Moisa M. (2008). Craiova lui Petre Pandrea. Craiova: Editura Ramuri.

[12] Bitoleanu Iulian, International Letters of Social and Humanistic Sciences 9 (2014) 116-121.

[13] Moisa M. (2011). Caleidoscop la purtător. Craiova: Editura Aius.

[14] Păun Mihaela Gabriela, International Journal of Education and Research 1(10) (2013).

[15] Vlăduțescu Ștefan (2013a). De ce s-ar numi ce facem noi aici Istoria presei românești /Istoria jurnalismului din România/ și pentru ce? În R. Bîlbîie, F. Șperlea \& M. Teodor (Coord), Jurnalismul, o preocupare a elitei. Studii și cercetări de istorie a presei (pp. 19-25). București: Editura Tritonic. 
[16] Pâslaru, Teodor (2011). Istoria oraşului Balş de la începuturi până la sfârşitu celui deal doilea război mondial. Balş: Editura: Premier LTD.

[17] Vlăduțescu, Ștefan (2013b). Câștig și pierdere de informație în analiza de intelligence. Fuziune, fisiune, comunicare. În G. C. Maior \& I. Nițu (Coord), Ars Analytica.

Provocări și tendințe în analiza de intelligence (pp. 309-327). București: Editura Rao.

[18] *** Licăriri, Balş, 1 august, 1915.

[19] Anghelescu Mircea (2013). Poarta neagră. MintRight Inc.

[20] *** Licăriri, Note de călătorie, IV, Balş, 2 februarie 1916.

[21] Smarandache, Florentin, \& Vlăduţescu, Ştefan (2014). Neutrosophic Emergences and Incidences in Communication and Information. Saarbrucken: LAP Lambert Academic Publishing.

[22] Strechie Mădălina (2010). O istorie a mentalităţilor şi a mijloacelor de comunicare din preistorie şi antichitate. Craiova: Editura Universitaria.

[23] Vlăduțescu Ștefan (a). Jokull Journal 63(9) (2013) 301-318.

[24] Vlăduţescu, Ştefan; Ciupercă, Ella Magdalena (2013). Next Flood Level of Communication: Social Networks. Aachen: Shaker Verlag.

[25] Vlăduţescu Ştefan (b), Jokull Journal 63(8) (2013) 186-197.

[26] Regneală, Mircea (2009). Noi studii de biblioteconomie. Asociația Bibliotecarilor din România.

[27] Vlăduţescu Ştefan (c), International Journal of Education and Research 1(11) (2013).

[28] Vlăduţescu Ştefan (d), International Journal of Education and Research 1(12) (2013).

[29] Siminică Marian; Traistaru Aurelia, International Journal of Education and Research 1(12) (2013).

[30] Borowski A. (c), International Letters of Social and Humanistic Sciences 4 (2013) 70-74.

[31] *** Dicţionarul istoric al localităţilor din judeţul Olt (2006). Craiova: Editura Alma. Gazeta Ţărăncuţa, anul I, no.1(1 septembrie 1929), Balş, Romanaţi.

[32] Dima Ioan Constantin, Vlăduţescu Ştefan (2012). Persuasion elements used in logistical negotiation: Persuasive logistical negotiation. Saarbrucken: LAP Lambert Academic Publishing.

[33] Hodoş Nerva, Ionescu Al. Sadi (1913). Publicaţiunile periodice româneşti. Tom I. Bucureşti: Biblioteca Academiei Române.

[34] Vlăduțescu Ștefan, International Letters of Social and Humanistic Sciences 7 (2014) 8-13.

[35] Moraru Mihai (1997). De nuptiis Mercurii et Philologiae. Editura Fundaţiei Culturale Române.

[36] Nowicka-Scowron M., Dima I. C., Vlăduţescu Ştefan, International Journal of Management Sciences and Business Research 1(8) (2012) 27-35. 
[37] Smarandache F., Vlăduţescu Ş. (2013). Communication vs. Information, a Neutrosophic Solution. Neutrosophic Sets and Systems.

[38] Grecu L. M., Păun M. G., European Journal of Humanities and Social Sciences 28(1) (2013).

[39] Vlăduțescu Ștefan, Mitteilungen Klosterneuburg Journal 64(1) (2014). 